\title{
DETERMINAN RETURN SAHAM PERUSAHAAN YANG TERDAFTAR DI JAKARTA ISLAMIC INDEX
}

\author{
Kartawati Mardiah ${ }^{1)}$ \& Desty Wana ${ }^{2)}$ \\ 1,2 Jurusan Akuntansi, Politeknik Negeri Pontianak \\ 1 email: kartawatimardiah@ymail.com \\ 2 email: destywana@gmail.com
}

\begin{abstract}
The problem in this study is whether the current ratio (CR), debt to equity ratio (DER), net profit margin (NPM) and risk (beta) have a partial or simultaneous effect on stock returns on companies listed on the Jakarta Islamic Index (JII) during the 2014-2018 period. The purpose of this study is to examine whether CR, DER, NPM, and beta have a partial or simultaneous effect on the stock returns of companies listed on JII during 2014-2018. This research uses quantitative research methods. The population is thirty companies registered in JII 2014-2018. The sample selection method used is purposive sampling. Samples that met the purposive sampling were ten companies listed on JII during the 2014-2018 period. The type of data is secondary data. Data analysis using multiple regression analysis models with SPSS. The results showed that Current Ratio (CR), Debt to Equity Ratio (DER), Net Profit Margin (NPM), and risk (Beta) simultaneously or partially had no effect on stock returns in JII in 2014-2018. The results of this study are expected to be useful as a material consideration for investors for investment decisions in the shares of companies listed on JII.
\end{abstract}

Keywords: current ratio, debt to equity, net profit margin, Sharia beta stocks, Sharia stock returns

\section{PENDAHULUAN}

Investasi saham syariah di Indonesia memiliki potensi besar untuk berkembang. Pertumbuhan investor syariah dari tahun 2017 ke 2018 meningkat hampir seratus persen. Potensi yang sangat besar ini dilatari karena penduduk Indonesia mayoritas muslim dan termasuk negara muslim terbesar di dunia (Lingga, 2019)

Minat investor yang ingin berinvestasi sesuai syariah didukung dengan dibentuknya Jakarta Islamic Index (JII), yaitu indeks saham syariah yang pertama kali diluncurkan di pasar modal Indonesia pada tanggal 3 Juli 2000. Konstituen JII hanya terdiri atas tiga puluh (30) saham syariah paling likuid yang tercatat di
Bursa Efek Indonesia (BEI) (Bursa Efek Indonesia, 2018a)

Pembentukan JII tidak lepas dari kerjasama antara Pasar Modal Indonesia (dalam hal ini PT Bursa Efek Jakarta) dengan PT Danareksa Invesment Management (PT DIM). Pembentukan instrumen syariah ini untuk mendukung pembentukan Pasar Modal Syariah yang kemudian diluncurkan di Jakarta pada tanggal 14 Maret 2003. Mekanisme Pasar Modal Syariah meniru pola serupa di Malaysia yang digabungkan dengan bursa konvensional seperti Bursa Efek Jakarta dan Bursa Efek Surabaya (Wikipedia, 2019). Bursa Efek Jakarta dan Bursa Efek Surabaya sekarang telah digabung menjadi Bursa Efek Indonesia (BEI). Hasil gabungan ini telah beroperasi sejak 1 Desember 2007. 
Tujuan pembentukan JII adalah untuk meningkatkan kepercayaan investor untuk melakukan investasi pada saham berbasis syariah dan memberikan manfaat bagi pemodal dalam menjalankan syariah Islam untuk melakukan investasi di bursa efek. JII juga diharapkan dapat mendukung proses transparansi dan akuntabilitas saham berbasis syariah di Indonesia (Wikipedia, 2019).

Seorang investor membeli suatu saham dengan harapan memperoleh hasil pengembalian (return) yang tinggi selama masa investasinya. Namun sering kali investor dihadapkan pada suatu kenyataan yang berbeda antara pengembalian nyata (actual return) dengan pengembalian yang diharapkan (expected return). Perbedaan antara hasil yang diharapkan dengan hasil kenyataan tersebut merupakan sumber risiko. Perbedaan anatara harapan dan kenyataan tersebut bersumber pada adanya suatu ketidakpastian (uncertainty) (Murhadi, 2009).

Penilaian investor terhadap suatu saham perusahaan di antaranya adalah dengan memperhatikan kinerja perusahaan yang menerbitkan saham. Karena itu return saham sangat penting bagi perusahaan karena digunakan sebagai salah satu pengukur kinerja dari suatu perusahaan sehingga perusahaan berusaha menjaga dan memperbaiki kinerjanya yang dapat mempengaruhi return saham agar portofolio saham yang diinvestasikannya meningkat.

Pertimbangan faktor ekonomi berupa return pada pasar modal syariah dapat ditunjukkan dengan kinerja karakteristik perusahaan. Karena itu investor memerlukan alat ukur yang memadai terhadap proyeksi keuntungan (return) perusahaan di masa mendatang dengan tingkat probabilitas yang berbeda-beda. Salah satu faktor alat ukur adalah informasi keuangan dari perusahaan tersebut untuk membuat keputusan investasi lebih menguntungkan dan membantu menilai potensi investasi berbagai saham di pasar modal. Karakteristik perusahaan dapat direfleksikan dalam analisis rasio keuangan. Rasio keuangan yang akan digunakan untuk memprediksi return saham di JII dalam penelitian ini adalah Current Ratio (CR), Debt to Equity Ratio (DER), Net Profit Margin (NPM), dan risiko (Beta) periode tahun 2014-2018.

Penelitian yang telah dilakukan di Bursa Efek Indonesia umumnya adalah kelompok saham real estate dan property (Sudarsono \& Sudiyatno, 2016), (Yuliaratih \& Artini, 2018), saham perusahaan manufaktur (Ginting, 2013), (Kristiana, 2013), (Arista \& Astohar, 2012), industri otomotif (Hermuningsih et al., 2018), (Anisa, 2015), industri barang konsumsi (Martono, 2017), agroindustry (Legiman et al., 2015), dan saham LQ-45 (Devaki, 2017), dengan variabel yang berbeda-beda. Sementara penelitian yang menganalisis kinerja saham syariah di JII (Haanurat, 2013) relatif masih sangat sedikit. Dengan alasan ini, maka dilakukan penelitian lebih lanjut tentang kinerja saham syariah yang berkaitan dengan return saham syariah dengan objek penelitian yang dikhususkan pada saham syariah yang tergabung dalam JII. Oleh karena itu penelitian ini berjudul Determinan Return Saham Perusahaan yang Terdaftar di Jakarta Islamic Index.

\section{KAJIAN LITERATUR DAN PEGEMBANGAN HIPOTESIS}

\section{Kajian Literatur \\ Return Saham}

Return merupakan hasil yang diperoleh dari investasi (Hartono, 2016). Dengan demikian return saham adalah hasil yang diperoleh investor atas suatu investasi yang dilakukannya dalam 
saham. Setiap investor selalu mengharapkan tingkat return yang sesuai atas setiap risiko investasi yang dihadapinya.

Return dapat berupa return realisasian (realized return) atau return ekspektasian (expected return). Return realisasian adalah return yang telah terjadi. Return realisasian dihitung menggunakan data historis. Return realisasian penting karena digunakan sebagai salah satu pengukur kinerja perusahaan. Return realisasian atau return histori ini juga berguna sebagai dasar penentuan return ekspektasian (expected return) dan risiko di masa datang (Hartono, 2016).

Return ekspektasian (expected return) adalah return yang diharapkan akan diperoleh investor di masa yang akan datang. Perbedaannya dengan return realisasian (realized return) adalah return ekspektasian (expected return) sifatnya belum terjadi.

Pengukuran return realisasian (realized return) yang banyak digunakan adalah return total (total return), relatif return (return relative), kumulatif return (return cumulative), dan return disesuaian (adjusted return). Return total merupakan return keseluruhan dari suatu investasi dalam suatu periode yang tertentu. Return total sering disebut dengan return saja (Hartono, 2016). Return total terdiri atas capital gain (loss) dan yield. Capital gain ataupun capital loss adalah selisih dari harga investasi sekarang relatif dengan harga periode yang lalu. Jika harga investasi sekarang lebih tinggi dari harga investasi periode lalu, maka ini berarti terjadi keuntungan modal (capital gain). Jika terjadi sebaliknya, maka ini berarti terjadi kerugian modal (capital loss).

Yield merupakan persentase penerimaan kas periodik terhadap harga investasi periode tertentu dari suatu investasi. Untuk saham, yield adalah persentase dividen terhadap harga saham periode sebelumnya (Hartono, 2016).

Return saham $\mathrm{R}_{\mathrm{i}}$ dihitung berdasarkan harga saham individual tahunan berikut ini.

$R_{i}=\left(P_{i t}-P_{i t-1}\right) / P_{i t-1}$

Notasi:

$\mathrm{R}_{\mathrm{i}}=$ Return saham

$\mathrm{P}_{\mathrm{it}}=$ Harga saham penutupan tahun $\mathrm{t}$

$\mathrm{P}_{\mathrm{it}-1}=$ Harga saham penutupan tahun $\mathrm{t}-1$

\section{Current Ratio (CR)}

Rasio yang paling umum digunakan untuk menganalisis posisi modal kerja suatu perusahaan adalah current ratio yaitu perbandingan antara jumlah aset lancar dengan utang lancar. CR yang tinggi memberikan indikasi jaminan yang baik bagi kreditor jangka pendek dalam arti setiap saat perusahaan memiliki kemampuan untuk melunasi kewajibankewajiban finansial jangka pendeknya (Anisa, 2015). Akan tetapi CR yang tinggi juga mengindikasikan sebagian modal kerja tidak berputar atau mengalami pengangguran dan akan berpengaruh negatif terhadap kemampuan memperoleh laba/rentabilitas (Martono \& Harjito, 2010). Berkurangnya kemampuan perusahaan dalam memperoleh laba akan menyebabkan penurunan juga pada return yang akan didapat oleh para investor (Anisa, 2015).

\section{Debt to Equity Ratio (DER)}

DER menunjukkan tingkat utang perusahaan. Perusahaan dengan nilai DER yang tinggi memiliki tingkat risiko kebangkrutan yang tinggi. Ketika terdapat penambahan jumlah utang secara absolut maka akan menurunkan tingkat solvabilitas perusahaan, yang selanjutnya akan berdampak dengan menurunnya nilai return perusahaan. Makin tinggi nilai DER, maka semakin rendah minat 
investor yang ingin berinvestasi, hal ini bisa dilihat dari harga saham yang rendah, sehingga menyebabkan return saham perusahaan tersebut menjadi semakin rendah. Ini membuktikan bahwa DER memiliki hubungan yang negatif dengan return saham.

Menurut (Darsono, 2005) Debt to Equity Ratio adalah rasio yang menunjukkan persentase penyedia dana oleh pemegang saham terhadap pemberi pinjaman. Semakin tinggi rasio, semakin rendah pendanaan perusahaan yang disediakan oleh pemegang saham. Dari perspektif kemampuan membayar kewajiban jangka panjang, semakin rendah rasio akan semakin baik kemampuan perusahaan dalam membayar kewajiban jangka panjangnya (Sudarsono \& Sudiyatno, 2016).

\section{Net Profit Margin (NPM)}

Net Profit Margin (NPM) adalah perbandingan antara laba bersih dengan penjualan. Kinerja suatu perusahaan akan dinilai produktif jika Net Profit Margin nya semakin meningkat (Suhardjono, 2006). Net Profit Margin (NPM), rasio ini menggambarkan besarnya laba bersih setelah pajak (Earning After Tax atau EAT) yang diperoleh perusahaan pada setiap penjualan yang dilakukan. Semakin tinggi Net Profit Margin perusahaan maka semakin baik kinerja perusahaan (Sumarsan, 2010). Dengan meningkatnya Net Profit Margin suatu perusahaan maka kepercayaan investor akan kemampuan perusahaan tersebut menghasilkan laba serta minat investor akan saham perusahaan tersebut, juga akan meningkat. Seiring dengan meningkatnya minat investor akan saham suatu perusahaan, akan menyebabkan harga saham tersebut mengalami peningkatan sehingga Return saham yang diperoleh juga meningkat.

Net Profit Margin (NPM) berfungsi untuk mengukur tingkat kembalian keuntungan bersih terhadap penjualan bersihnya. NPM perusahaan yang meningkat akan menyebabkan investor memburu suatu saham perusahaan sehingga akibatnya return perusahaan tersebut akan meningkat pula (Martono, 2017).

\section{Beta}

Menurut (Hartono, 2016) beta merupakan suatu pengukur volatilitas (volatility) return suatu sekuritas atau return portofolio terhadap return pasar. Beta sekuritas ke-i mengukur volatilitas return sekuritas ke-i dengan return pasar. Beta portofolio mengukur volatilitas return portofolio dengan return pasar. Dengan demikian, beta merupakan pengukur risiko sistematis (systematic risk) dari suatu sekuritas atau portofolio relatif terhadap risiko pasar.

Beta suatu sekuritas atau portofolio ditunjukkan dengan koefisien Beta yang diukur dengan slope yang diperoleh dari regresi return saham dengan return pasar. Beta $=1$, artinya bahwa setiap satu persen perubahan return pasar baik naik ataupun turun maka return saham atau potofolio juga akan bergerak sama besarnya mengikuti return pasar. Saham yang mempunyai nilai Beta $>1$ dikatakan sebagai saham agresif, artinya tingkat kepekaan saham tersebut terhadap perubahan pasar sangat tinggi atau dapat juga dikatakan memiliki risiko yang lebih besar dari tingkat risiko rata-rata pasar. Saham yang mempunyai Beta $<1$ mengindikasikan bahwa saham bersifat defensif (conservative), artinya saham tersebut kurang peka terhadap perubahan pasar dan memiliki risiko dibawah ratarata pasar. Beta saham merupakan hasil regresi antara return perusahaan yang dihitung dari perubahan harga saham perusahaan pada akhir bulan dengan return pasar yang dihitung dari perubahan 
rata-rata bulanan indeks harga di JII setiap akhir tahun.

Beta $\left(\mathrm{X}_{4}\right)$ saham sebagai variabel independen diukur menggunakan persamaan dari model indeks tunggal atau model pasar (market model) sebagai berikut:

$R_{i}=\alpha_{i}+\beta_{i} R_{m}+\varepsilon_{t} \ldots \ldots \ldots \ldots \ldots$.

Notasi:

$\mathrm{R}_{\mathrm{i}}=$ Return sekuritas ke- $\mathrm{i}$

$\alpha_{\mathrm{i}}=$ suatu variabel acak yang menunjukkan komponen dari return sekuritas ke-i yang independen terhadap kinerja pasar,

$\beta_{\mathrm{i}}=$ Beta saham, yang merupakan koefisien yang mengukur perubahan $R_{i}$ akibat perubahan $R_{m}$

$\mathrm{R}_{\mathrm{m}}=$ Return pasar, tingkat return dari indeks pasar, juga merupakan suatu variabel acak.

$\mathcal{E}_{\mathrm{t}}=$ residual selama periode $\mathrm{t}$ (Hartono, 2016:408 dan 448)

Penghitungan return pasar dilakukan menggunakan persamaan:

$R_{m}=\left(R_{m t}-R_{m t-1}\right) / R_{m t-1} \quad \ldots \ldots$

Notasi:

$\mathrm{R}_{\mathrm{m}}=$ Return pasar

$\mathrm{R}_{\mathrm{mt}}=$ indeks harga di JII pada tahun $\mathrm{t}$

$\mathrm{R}_{\mathrm{mt}-1}=$ indeks harga di JII pada tahun $\mathrm{t}-1$.

Untuk return saham $R_{i}$ dihitung berdasarkan harga saham individual tahunan.

$R_{i}=\left(P_{i t}-P_{i t-1}\right) / P_{i t-1}$

Notasi:

$\mathrm{R}_{\mathrm{i}}=$ Return saham

$P_{i t}=$ Harga saham penutupan tahun $t$

$\mathrm{P}_{\mathrm{it}-1}=$ Harga saham penutupan tahun $\mathrm{t}-1$

\section{Penelitian Terdahulu}

Seperti telah diuraikan sebelumnya, penelitian terhadap faktor-faktor yang memengaruhi return saham telah dilakukan dengan variabel-variabel independen yang berbeda-beda, sektor perusahaan yang diteliti juga berbeda- beda, dan hasilnya juga berbeda-beda. Secara garis besar penelitian-penelitian terdahulu mengenai faktor-faktor yang memengaruhi return saham dapat diringkas sebagaimana ditampilkan pada Tabel 1 Review Penelitian Terdahulu pada lampiran.

\section{Model Penelitian}

Model penelitian menggambarkan kerangka konseptual hipotesis yang digambarkan pada Gambar 1 sebagai berikut:

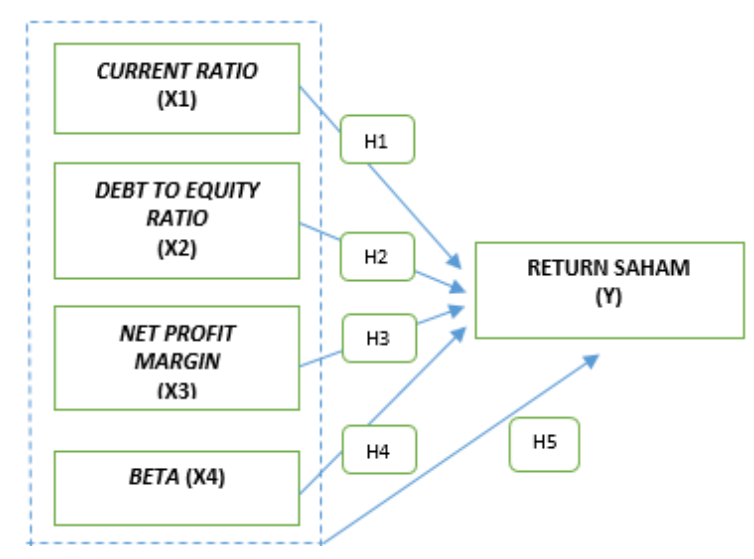

\section{Gambar 1. Model Penelitian}

\section{Pengembangan Hipotesis}

Berdasarkan teori pada tinjauan pustaka dan penelitian empiris pada Tabel 1 Review Penelitian Terdahulu (pada Lampiran) tersebut maka dapat dibuat hipotesis sebagai berikut:

\section{Pengaruh CR terhadap return saham}

CR yang tinggi memberikan indikasi jaminan yang baik bagi kreditor jangka pendek dalam arti setiap saat perusahaan memiliki kemampuan untuk melunasi kewajiban-kewajiban finansial jangka pendeknya (Anisa, 2015). Akan tetapi CR yang tinggi juga mengindikasikan sebagian modal kerja tidak berputar atau mengalami pengangguran dan akan berpengaruh negatif terhadap kemampuan memperoleh laba/rentabilitas (Martono \& 
Harjito, 2010). Berkurangnya kemampuan perusahaan dalam memperoleh laba akan menyebabkan penurunan juga pada return yang akan didapat oleh para investor (Anisa, 2015).

Penelitian yang dilakukan (Ulupui, 2007) menunjukkan bahwa CR memiliki pengaruh yang positif dan signifikan terhadap return saham satu periode ke depan. Hal ini mengindikasikan bahwa investor akan memperoleh return yang lebih tinggi jika kemampuan perusahaan memenuhi kewajiban jangka pendeknya semakin tinggi, karena setelah krisis ekonomi investor mulai memperhatikan manajemen kas, piutang, dan persediaan perusahaan sebelum mengambil keputusan berinvestasi di pasar modal.

Current ratio (CR) menunjukkan kemampuan perusahaan dalam memenuhi kewajiban jangka pendek dan membiayai kegiatan operasional. CR yang tinggi menunjukkan perusahaan dalam kondisi liquid. Perusahaan yang liquid lebih menarik minat investor. Jika banyak investor yang tertarik membeli saham perusahaan tersebut, maka harga saham perusahaan itu akan naik dan return saham perusahaan tersebut juga akan meningkat. Hal ini menunjukkan Current ratio dan return saham memiliki hubungan yang positif (Haanurat, 2013).

Hasil penelitian empiris, CR tidak berpengaruh signifikan terhadap return saham syariah perusahaan di JII tahun 2008-2012 (Haanurat, 2013). Demikian juga hasil penelitian Anisa (2015) CR tidak berpengaruh signifikan terhadap return saham perusahaan sub sektor otomotif di BEI tahun 2010-2014. Hasil temuan ini mendukung hasil penelitian (Kusumo, 2011) yang menemukan bahwa CR tidak berpengaruh secara signifikan terhadap return saham, namun bertentangan dengan hasil penelitian (Prihantini, 2009) yang menyatakan bahwa CR berpengaruh secara signifikan terhadap return saham. Sementara hasil penelitian (Anisa, 2015) mendukung penelitian yang dilakukan oleh (Farkhan \& Ika, 2012), (Thrisye \& Simu, 2013), dan (Antara et al., 2014) yang menyatakan bahwa CR tidak berpengaruh signifkan terhadap return saham. Namun, hasil tersebut tidak sejalan dengan penelitian yang dilakukan oleh (Ulupui, 2007) yang menyatakan bahwa CR memiliki pengaruh positif dan signifikan terhadap return saham (Anisa, 2015).

H1: CR berpengaruh terhadap return saham syariah di JII pada tahun 20142018

\section{Pengaruh DER terhadap return saham}

Hasil penelitian empiris, DER berpengaruh negatif signifikan terhadap return saham perusahaan properti dan real estate di BEI tahun 2009-2014 (Sudarsono \& Sudiyatno, 2016) dan hasil penelitian (Anisa, 2015) DER berpengaruh positif dan signifikan terhadap return saham perusahaan sub sektor otomotif di BEI tahun 2010-2014. Hal ini berbeda dengan hasil penelitian (Legiman et al., 2015) dan (Haanurat, 2013) yang menyatakan DER tidak berpengaruh signifikan terhadap return saham perusahaan agroindustri tahun 2009-2012 (Legiman et al., 2015) dan perusahaan di JII tahun 2008-2012 (Haanurat, 2013).

H2: DER berpengaruh terhadap return saham syariah di JII pada tahun 20142018.

\section{Pengaruh NPM terhadap return saham}

Hasil penelitian empiris, NPM tidak berpengaruh terhadap saham perusahaan manufaktur di BEI tahun 2008-2011 (Ginting, 2013). Sementara hasil penelitian (Martono, 2017) NPM berpengaruh positif terhadap return saham perusahaan industri barang konsumsi di BEI tahun 2010-2013. 
H3: NPM berpengaruh terhadap return saham syariah di JII pada tahun 20142018

\section{Pengaruh beta terhadap return saham}

Penelitian yang dilakukan oleh (Yunina \& Shabri, 2013) menemukan bahwa risiko sistematik (beta) berpengaruh positif terhadap return saham. Namun hal ini berbeda dengan hasil penelitian yang dikemukakan oleh (Sugiarto, 2011) yang menyatakan bahwa risiko sistematik (beta) tidak berpengaruh terhadap return saham. Dengan demikian, terdapat perbedaan hasil penelitian mengenai hubungan antara risiko sistematik (beta) terhadap return saham.

Hasil penelitian (Hermuningsih et al., 2018) dan (Devaki, 2017) menyatakan bahwa Beta berpengaruh positif yang signifikan terhadap return saham pada perusahaan manufaktur yang dikategorikan pada perusahaan subsektor otomotif di BEI tahun 2011-2015 (Hermuningsih et al., 2018) dan perusahaan yang termasuk dalam indeks LQ 45 (Devaki, 2017).

H4: Beta berpengaruh terhadap return saham syariah di JII pada tahun 20142018

\section{Pengaruh CR, DER, NPM, dan Beta terhadap return saham}

Berdasarkan hipotesis 1 (H1) sampai hipotesis 4 (H4) sebelumnya maka dapat dibuat hipotesis 5 (H5) sebagai berikut.

H5: CR, DER, NPM, dan Beta secara bersama-sama berpengaruh terhadap return saham syariah di JII pada tahun 2014-2018

\section{METODE PENELITIAN}

\section{Bentuk Penelitian}

Penelitian ini merupakan penelitian kuantitatif jika dilihat dari sudut pandang paradigma (pendekatan) penelitian.
Penelitian kuantitatif adalah penelitian yang menekankan pada kombinasi antara logika deduktif dan penggunaan alat-alat kuantitatif atau analisis data dengan prosedur statistik dalam menginterpretasikan suatu fenomena secara objektif. Dalam pendekatan deduktif, penelitian dilakukan untuk menguji hipotesis melalui pengujian data atau fenomena untuk membuktikan hubungan antara variabel-variabel yang diteliti (Hendriyani et al., 2017).

Berdasarkan tujuan penelitian, penelitian ini termasuk ke dalam jenis penelitian terapan dan penelitian explanatory. Penelitian terapan adalah penelitian yang menekankan pada pemecahan masalah-masalah praktis. Penelitian ini diarahkan untuk menjawab pertanyaan spesifik dalam rangka penentuan kebijakan, tindakan atau kinerja tertentu (Hendriyani et al., 2017). Penelitian explanatory adalah penelitian yang bertujuan menghubungkan atau menjelaskan antara dua variabel, misalkan penelitian yang bertema hubungan atau pengaruh, dan bertujuan membuktikan hipotesis atau menguji sebuah teori (Zulganef, 2008).

Berdasarkan karakteristik masalah yang diteliti, penelitian ini termasuk jenis penelitian deskriptif. Penelitian deskriptif (descriptive research), merupakan penelitian terhadap masalah-masalah berupa fakta-fakta saat ini dari suatu populasi. Tujuan penelitian ini untuk menguji hipotesis atau menjawab pertanyaan yang berkaitan dengan current status dari subyek yang diteliti (Hendriyani et al., 2017).

\section{Variabel Penelitian dan Pengukurannya}

Variabel yang digunakan dalam penelitian ini adalah variabel independen (bebas) dan variabel dependen (terikat). Variabel independennya yaitu $\mathrm{CR}\left(\mathrm{X}_{1}\right)$, 
DER $\left(\mathrm{X}_{2}\right)$, NPM $\left(\mathrm{X}_{3}\right)$, dan Beta $\left(\mathrm{X}_{4}\right)$. Sementara return saham syariah $(\mathrm{Y})$ sebagai variabel dependen (terikat).

Current Ratio (CR) adalah alat ukur kemampuan likuiditas yaitu kemampuan untuk membayar utang jangka pendek yang segera harus dipenuhi dengan aset lancar $\left(\mathrm{X}_{1}\right)$. Debt to Equity Ratio (DER) adalah rasio solvabilitas yang diperoleh dari perbandingan antara seluruh kewajiban dengan modal sendiri yang dimiliki emiten $\left(\mathrm{X}_{2}\right)$. Rasio ini digunakan untuk mengukur kemampuan modal sendiri untuk dijadikan sebagai jaminan semua utang. NPM $\left(X_{3}\right)$, rasio ini menggambarkan besarnya laba bersih setelah pajak (Earning After Tax atau EAT) yang diperoleh perusahaan pada setiap penjualan (sales) yang dilakukan. Semakin tinggi NPM perusahaan maka semakin baik kinerja perusahaan (Sumarsan, 2010). Beta $\left(\mathrm{X}_{4}\right)$ merupakan pengukur risiko sistematis (systematic risk) dari suatu sekuritas atau portofolio relatif terhadap risiko pasar. Return saham syariah (Y) adalah hasil yang diperoleh dari penanaman modal saham syariah pada periode tertentu. Return saham merupakan hasil investasi surat berharga (saham) yang berupa capital gain (loss) yaitu selisih antara harga saham saat ini (closing price pada periode $\mathrm{t}$ ) dengan harga saham periode sebelumnya (closing price pada periode $\mathrm{t}-1$ ) dibagi dengan harga saham periode sebelumnya (closing price pada periode t-1). Variabel-variabel ini dapat diringkas sebagaimana pada Tabel 2 Definisi Operasional Variabel berikut ini.

Tabel 2. Definisi Operasional Variabel

\begin{tabular}{llc}
\hline \multicolumn{1}{c}{ Variabel } & \multicolumn{1}{c}{ Definisi Variabel } & Parameter \\
\hline Return & $\begin{array}{l}\text { Selisih harga saham periode t dengan harga saham } \\
\text { periode sebelumnya (t-1) }\end{array}$ & $R_{t}=\frac{P_{t}-P_{t-1}}{P_{t-1}}$ \\
\hline CR $(\mathrm{X} 1)$ & $\begin{array}{l}\text { Rasio untuk mengetahui berapa aset lancar digunakan } \\
\text { untuk melunasi utang lancar yang akan jatuh tempo }\end{array}$ & CR $=\frac{\text { Current Assets }}{\text { Current Liabilities }}$ \\
\hline DER (X2) & Perbandingan antara jumlah utang dengan modal & DER $=\frac{\text { Total Liabilities }}{\text { Total Equities }}$ \\
\hline NPM (X3) & $\begin{array}{l}\text { Rasio untuk menilai kemampuan perusahaan untuk } \\
\text { menghasilkan laba }\end{array}$ & NPM $=\frac{\text { EAT }}{\text { Sales }}$ \\
\hline Beta (X4) & $\begin{array}{l}\text { pengukur risiko sistematik dari suatu sekuritas atau } \\
\text { portofolio relatif terhadap risiko pasar }\end{array}$ & $R_{i}=\alpha_{i}+\beta_{i} R_{m}+\varepsilon_{i}$ \\
\hline
\end{tabular}

\section{Populasi dan Sampel}

Metode pemilihan sampel adalah dengan purposive sampling, dengan kriteria sebagai berikut: (1) perusahaan emiten terdaftar di Jakarta Islamic Index (JII) selama periode 2014-2018, (2) perusahaan emiten menerbitkan laporan keuangan dari tahun 2014-2018, disajikan dalam rupiah, dan memiliki kelengkapan data.

\section{Data dan Pengumpulan Data}

Data yang diperlukan adalah (1) data laporan keuangan per 31 Desember 20142018, laporan tahunan, dan ringkasan kinerja perusahaan yang terdaftar di JII tahun 2014-2018 yang memenuhi kriteria purposive sampling, diunduh dari website PT Bursa Efek Indonesia (BEI) https://www.idx.co.id (Bursa Efek Indonesia, 2018b) (2) data harga saham bulanan dari setiap perusahaan yang 
memenuhi kriteria purposive sampling, diperoleh dari ringkasan kinerja yang diunduh dari website PT Bursa Efek Indonesia (BEI) https://www.idx.co.id (Bursa Efek Indonesia, 2018d) atau https://finance.yahoo.com

(Finance.yahoo.com, 2018) atau https://www.duniainvestasi.com (Dunia Investasi, 2018) dan (3) data indeks harga saham di JII yang dapat diunduh dari website PT Bursa Efek Indonesia (BEI) https://www.idx.co.id (Bursa Efek Indonesia, 2018c).

Berdasarkan data yang ada dari laporan keuangan dihitung rasio-rasionya. Data harga saham harian diolah lagi sehingga menjadi data beta saham dan return saham dengan menggunakan rumus-rumus yang telah ditampilkan pada Tabel 2 Definisi Operasional Variabel. Kemudian dilakukan tabulasi data.

Pengumpulan data dari 30 (tiga puluh) perusahaan yang terdaftar di JII secara terus-menerus ada pada tahun 2014-2018 diperoleh 14 (empat belas) perusahaan. Kemudian dari empat belas (14) perusahaan ini dua (2) perusahaan tidak lengkap datanya dan dua (2) perusahaan lainnya laporan keuangan disajikan dalam mata uang selain rupiah. Dengan demikian tersisa sepuluh (10) perusahaan yang menjadi sampel. Daftar kesepuluh perusahaan tersebut terlampir (Lampiran 2).

\section{Analisis Data}

Data yang ada terlebih dahulu diuji dengan uji asumsi klasik. Analisis data yang digunakan untuk menguji hipotesis adalah analisis regresi berganda dengan SPSS. Persamaan regresi dalam penelitian ini adalah:

$$
\begin{aligned}
\mathrm{Y}= & \mathrm{a}_{0}+\mathrm{b}_{1} \mathrm{CR}+\mathrm{b}_{2} \mathrm{DER}+\mathrm{b}_{3} \mathrm{NPM}+ \\
& \mathrm{b}_{4} \mathrm{BETA}+\mathrm{e}_{\mathrm{i}}
\end{aligned}
$$

Notasi:

$\mathrm{Y}=$ Return saham perusahaan di JII;

$\mathrm{b}_{1}=$ Current Ratio;

$\mathrm{b}_{2}=$ Debt to Equity Ratio

$\mathrm{b}_{3}=$ Net Profit Margin

$\mathrm{b}_{4}=$ Beta

$\mathrm{e}=$ error term

\section{HASIL DAN PEMBAHASAN}

\section{Statistik Deskriptif}

Proses pemilihan sampel dalam penelitian ini menghasilkan sepuluh observasi perusahaan untuk periode penelitian tahun 2014-2018. Untuk memperoleh gambaran secara umum mengenai data sampel penelitian, Tabel 3 memperlihatkan gambaran statistik tentang data sampel secara keseluruhan.

\section{Tabel 3. Statistik Deskriptif}

\begin{tabular}{|l|r|r|r|r|r|}
\hline \multicolumn{1}{l|}{ Descriptive Statistics } \\
\hline Current Ratio (X1) & $\mathrm{N}$ & Minimum & Maximum & \multicolumn{1}{c|}{ Mean } & Std. Deviation \\
Debt to Equity Ratio (X2) & 50 & .61 & 4.66 & 1.8652 & .96953 \\
Net Profit Margin (X3) & 50 & .19 & 2.65 & 1.0848 & .68693 \\
Beta (X4) & 50 & .04 & .71 & .1512 & .12242 \\
Return Saham (Y) & 10 & -1.254 & 2.389 & 1.13920 & .969812 \\
Valid N (listwise) & 50 & -.364 & 1.569 & .10765 & .398620 \\
\hline
\end{tabular}

Pada Tabel 3 dapat dilihat bahwa variabel return saham memiliki nilai terendah $-0,364$ dan nilai tertinggi 1,569 dengan nilai rata-rata 0,10765 dan deviasi standar 0,398620. Analisis deskriptif pada variabel Current Ratio (CR) didapatkan nilai terendah 0,61 dan nilai tertinggi 4,66 dengan nilai rata-rata 1,8652 dan deviasi 
standar 0,96953. Analisis deskriptif pada variabel Debt to Equity Ratio (DER) didapatkan nilai terendah 0,19 dan nilai tertinggi 2,65 dengan nilai rata-rata 1,0848 dan deviasi standar 0,68693.

Hasil analisis deskriptif pada variabel Net Profit Margin (NPM) didapatkan nilai terendah 0,04 dan nilai tertinggi 0,71 dengan nilai rata-rata 0,1512 dan deviasi standar 0,12242. Analisis deskriptif pada variabel Beta didapatkan nilai terendah 1,254 dan nilai tertinggi 2,389 dengan nilai rata-rata 1,13920 dan deviasi standar 0,969812 .

\section{Uji Asumsi Klasik}

Sebelum dilakukan pengujian hipotesis menggunakan pengujian secara statistik yaitu uji $\mathrm{F}$ dan uji t juga dilakukan uji terhadap penyimpangan asumsi klasik. Pengujian ini dilakukan untuk menguji validitas dari hasil analisis regresi linier berganda. Adapun pengujian yang digunakan adalah uji multikolinearitas, uji autokorelasi, uji heteroskedastisitas dan uji normalitas.
Uji multikolinearitas bertujuan untuk menguji apakah dalam model regresi ditemukan adanya korelasi antar variabel bebas (independen). Model regresi yang baik seharusnya tidak terjadi korelasi di antara variabel bebas (tidak terjadi multikolinearitas). Jika variabel bebas saling berkorelasi, maka variabel-variabel ini tidak orthogonal. Variabel orthogonal adalah variabel independen yang nilai korelasi antar sesama variabel independen sama dengan nol. (Ghozali, 2013).

Multikolinearitas dapat dilihat dari nilai Tolerance dan nilai variance inflation factor (VIF). Jika nilai Tolerance lebih besar dari 0,10 maka berarti tidak terjadi multikolinearitas terhadap data yang diuji. Sebaliknya jika nilai Tolerance lebih kecil dari 0,10 maka berarti terjadi multikolinearitas terhadap data yang diuji. Jika nilai VIF lebih kecil dari 10 maka artinya tidak terjadi multikolinearitas terhadap data yang diuji. Sebaliknya jika nilai VIF lebih besar dari 10 maka artinya terjadi multikolinearitas terhadap data yang diuji (Raharjo, 2014).

\section{Uji Multikolinearitas}

\section{Tabel 4. Hasil Uji Multikolinearitas}

\begin{tabular}{|c|c|c|c|c|c|c|c|c|}
\hline \multicolumn{9}{|c|}{ Coefficients $^{a}$} \\
\hline \multirow{2}{*}{\multicolumn{2}{|c|}{ Model }} & \multicolumn{2}{|c|}{ Unstandardized Coefficients } & \multirow{2}{*}{$\begin{array}{c}\begin{array}{c}\text { Standardized } \\
\text { Coefficients }\end{array} \\
\text { Beta }\end{array}$} & \multirow[b]{2}{*}{$t$} & \multirow[b]{2}{*}{ Sig. } & \multicolumn{2}{|c|}{ Collinearity Statistics } \\
\hline & & $\mathrm{B}$ & Std. Error & & & & Tolerance & VIF \\
\hline \multirow[t]{5}{*}{1} & (Constant) & -.394 & 1.108 & & -.355 & .737 & & \\
\hline & Current Ratio (X1) & .074 & .403 & .101 & .184 & .861 & .335 & 2.986 \\
\hline & Debt to Equity Ratio $\left(X_{2}\right)$ & .294 & .441 & .350 & .668 & .534 & .364 & 2.748 \\
\hline & Net Profit Margin (X3) & .069 & .972 & .024 & .071 & .946 & .890 & 1.123 \\
\hline & Beta $(\times 4)$ & .386 & .216 & .647 & 1.786 & .134 & .760 & 1.316 \\
\hline
\end{tabular}

a. Dependent Variable: Return Saham ( $($ )

Berdasarkan Tabel 4 Hasil Uji Multikolinearitas, diketahui nilai Tolerance untuk variabel CR (X1) 0,335, DER (X2) 0,364, NPM (X3) 0,890, dan Beta (X4) 0,760. Masing-masing nilai Tolerance tersebut lebih besar dari 0,10. Sementara nilai VIF untuk setiap variabel antara nilai 1,123 sampai dengan 2,986. Semua nilai VIF tersebut kurang dari 10. Maka dapat disimpulkan bahwa tidak terjadi multikolinearitas dalam model regresi ini. 


\section{Uji Autokorelasi (Run Test)}

Uji autokorelasi bertujuan menguji apakah dalam suatu model regresi linear terdapat korelasi antara kesalahan pengganggu pada periode $t$ dengan kesalahan pada periode t-1 (Ghozali, 2013). Salah satu asumsi dalam model regresi linear klasik (MRLK) adalah tidak ada autokorelasi di antara dua faktor kesalahan acak (Gujarati, 2006).

Pengujian autokorelasi dapat dilakukan dengan salah satu cara yaitu Run Test. Dasar pengambilan keputusan dalam Run Test adalah jika nilai Asymp. Sig. (2-tailed) lebih kecil dari 0,05 maka terdapat gejala autokorelasi. Sebaliknya jika nilai Asymp. Sig. (2-tailed) lebih besar dari 0,05 maka tidak terdapat gejala autokorelasi (Raharjo, 2017). Hasil output SPSS Run Test dapat dilihat pada Tabel 5.

\section{Tabel 5. Hasil Uji Autokorelasi Runs Test}

Runs Test

\begin{tabular}{|l|r|}
\hline & $\begin{array}{c}\text { Unstandardiz } \\
\text { ed Residual }\end{array}$ \\
\hline Test Value $^{\text {a }}$ & .00893 \\
Cases $<$ Test Value & 5 \\
Cases $>=$ Test Value & 5 \\
Total Cases & 10 \\
Number of Runs & 7 \\
Z & .335 \\
Asymp. Sig. (2-tailed) & .737 \\
\hline
\end{tabular}

a. Median
Berdasarkan hasil pada Tabel 5 Hasil Uji Autokorelasi Runs Test, diketahui nilai Asymp. Sig. (2-tailed) sebesar 0,737. Nilai ini lebih besar dari 0,05. Maka dapat disimpulkan bahwa tidak terdapat gejala atau masalah autokorelasi, sehingga analisis regresi linear dapat dilanjutkan.

\section{Uji Heteroskedastisitas (Uji Glejser)}

Heteroskedastisitas akan mengakibatkan penaksiran koefisienkoefisien regresi menjadi tidak efisien. Hasil penaksiran akan menjadi kurang dari semestinya. Heteroskedastisitas bertentangan dengan salah satu asumsi dasar regresi linear, yaitu bahwa variasi residual sama untuk semua pengamatan atau disebut homoskedastisitas (Gujarati, 2006). Untuk menguji tidak terjadinya heteroskedastisitas dilakukan dengan salah satu cara yaitu uji Glejser.

Dasar pengambilan keputusan untuk menentukan kesimpulan hasil uji heteroskedastisitas (uji glejser) ini adalah jika nilai signifikansi lebih besar dari 0,05, kesimpulannya adalah tidak terjadi heteroskedastisitas. Sebaliknya jika nilai signifikansi lebih kecil dari 0,05, kesimpulannya adalah terjadi heteroskedastisitas.

Hasil SPSS uji heteroskedastisitas Glejser dapat dilihat pada Tabel 6 .

Tabel 6. Hasil Uji Heteroskedastisitas (Uji Glejser)

Coefficients $^{a}$

\begin{tabular}{|c|c|c|c|c|c|c|}
\hline \multirow[b]{2}{*}{ Mod } & & \multicolumn{2}{|c|}{ Unstandardized Coefficients } & \multirow{2}{*}{$\begin{array}{c}\begin{array}{c}\text { Standardized } \\
\text { Coefficients }\end{array} \\
\text { Beta }\end{array}$} & \multirow[b]{2}{*}{$t$} & \multirow[b]{2}{*}{ Sig. } \\
\hline & & $B$ & Std. Error & & & \\
\hline \multirow[t]{5}{*}{1} & (Constant) & .443 & .600 & & .739 & .493 \\
\hline & Current Ratio (X1) & .033 & .218 & .099 & .152 & .885 \\
\hline & Debt to Equity Ratio $(X 2)$ & -.060 & .239 & -.158 & -.252 & .811 \\
\hline & Net Profit Margin (X3) & -.709 & .527 & -.540 & -1.347 & .236 \\
\hline & Beta $(X 4)$ & -.004 & .117 & -.014 & -.032 & .976 \\
\hline
\end{tabular}

a. Dependent Variable: Abs_RES 
Berdasarkan Tabel 6 Hasil Uji Heteroskedastisitas (Uji Glejser), diketahui nilai signifikansi (Sig.) untuk variabel CR 0,885, DER 0,811, NPM 0,236, dan Beta 0,976. Nilai-nilai tersebut lebih besar dari 0,05. Maka dapat disimpulkan tidak terjadi gejala heteroskedastisitas dengan menggunakan uji glejser dalam model regresi ini.

\section{Uji Normalitas}

Uji normalitas bertujuan untuk menguji apakah data penelitian yang dilakukan memiliki distribusi yang normal atau tidak. Data yang baik adalah data yang normal pendistribusiannya. Uji normalitas dapat dilakukan dengan salah satu cara yaitu uji Kolmogorov-Smirnov.

Dasar pengambilan keputusan dalam uji normalitas ini adalah jika nilai signifikansi lebih besar dari 0,05 maka data tersebut berdistribusi normal. Sebaliknya, jika nilai signifikansi lebih kecil dari 0,05 maka data tersebut tidak berdistribusi normal.

Hasil output SPSS uji normalitas Kolmogorov-Smirnov dapat dilihat pada Tabel 7.

Tabel 7. Hasil Uji Normalitas Kolmogorov-Smirnov

One-Sample Kolmogorov-Smirnov Test

\begin{tabular}{|ll|r|}
\hline & & $\begin{array}{r}\text { Unstandardiz } \\
\text { ed Residual }\end{array}$ \\
\hline $\mathrm{N}$ & Mean & 10 \\
Normal Parameters & a,b & .0000000 \\
Most Extreme Differences & Std. Deviation & .40888021 \\
& Absolute & .143 \\
& Positive & .143 \\
Test Statistic & Negative & -.108 \\
Asymp. Sig. (2-tailed) & & .143 \\
\hline
\end{tabular}

a. Test distribution is Normal.

b. Calculated from data.

c. Lilliefors Significance Correction.

d. This is a lower bound of the true significance.
Berdasarkan Tabel 7 Hasil Uji Normalitas Kolmogorov-Smirnov, hasil Asymp. Sig. (2-tailed) sebesar 0,200 lebih besar dari 0,05. Dengan demikian dapat diambil kesimpulan data yang diuji berdistribusi normal.

\section{Uji Hipotesis}

\section{Hasil Uji F}

Uji $F$ bertujuan untuk mengetahui pengaruh variabel $\mathrm{X}$ secara simultan (bersama-sama) terhadap vaiabel $\mathrm{Y}$. Hipotesis yang diajukan dalam Uji F ini adalah Current Ratio (CR), Debt to Equity Ratio (DER), Net Profit Margin (NPM), dan risiko (Beta) secara bersama-sama berpengaruh terhadap return saham di JII pada tahun 2014-2018.

Dasar pengambilan keputusan dalam Uji $\mathrm{F}$ adalah jika nilai Sig. kurang dari 0,05 maka hipotesis diterima. Namun jika nilai Sig. lebih besar dari 0,05 maka hipotesis ditolak.

\section{Tabel 8. Hasil Uji F}

\begin{tabular}{|c|c|c|c|c|c|c|}
\hline \multicolumn{7}{|c|}{ ANOVA $^{a}$} \\
\hline Mode & & $\begin{array}{l}\text { Sum of } \\
\text { Squares }\end{array}$ & df & Mean Square & $\mathrm{F}$ & Sig. \\
\hline \multirow[t]{3}{*}{1} & Regression & 1.513 & 4 & .378 & 1.257 & $.396^{\mathrm{b}}$ \\
\hline & Residual & 1.505 & 5 & .301 & & \\
\hline & Total & 3.018 & 9 & & & \\
\hline
\end{tabular}

Berdasarkan Tabel 8 Hasil Uji F, nilai Sig. 0,396 adalah lebih besar dari 0,05. Maka dapat disimpulkan bahwa hipotesis ditolak. Hal ini berarti Current Ratio (CR), Debt to Equity Ratio (DER), Net Profit Margin (NPM), dan risiko (Beta) secara bersama-sama tidak berpengaruh terhadap return saham di JII pada tahun 2014-2018. 


\section{Hasil Uji t}

Uji $\mathrm{t}$ bertujuan untuk mengetahui pengaruh variabel bebas atau variabel independen (X) secara parsial terhadap variabel terikat atau variabel dependen (Y). Hipotesis yang diajukan dalam penelitian ini adalah Current Ratio (CR), Debt to Equity Ratio (DER), Net Profit Margin (NPM) dan Beta berpengaruh terhadap return saham di JII pada tahun 2014-2018.

Dasar pengambilan keputusan dalam Uji t adalah jika nilai Sig. kurang dari 0,05 maka hipotesis diterima. Namun jika nilai Sig. lebih besar dari 0,05 maka hipotesis ditolak.

\section{Tabel 9 Hasil Uji t}

Coefficients $^{\mathrm{a}}$

\begin{tabular}{|c|c|c|c|c|c|c|}
\hline \multirow[b]{2}{*}{ Mod } & & \multicolumn{2}{|c|}{ Unstandardized Coefficients } & \multirow{2}{*}{$\begin{array}{c}\begin{array}{c}\text { Standardized } \\
\text { Coefficients }\end{array} \\
\text { Beta }\end{array}$} & \multirow[b]{2}{*}{$t$} & \multirow[b]{2}{*}{ Sig. } \\
\hline & & $\mathrm{B}$ & Std. Error & & & \\
\hline \multirow[t]{5}{*}{1} & (Constant) & -.394 & 1.108 & & -.355 & .737 \\
\hline & Current Ratio (X1) & .074 & .403 & 101 & .184 & .861 \\
\hline & Debt to Equity Ratio $(X 2)$ & .294 & .441 & .350 & .668 & .534 \\
\hline & Net Profit Margin $(X 3)$ & .069 & .972 & .024 & .071 & .946 \\
\hline & Beta $(\times 4)$ & .386 & .216 & .647 & 1.786 & .134 \\
\hline
\end{tabular}

a. Dependent Variable: Return Saham (V)

Berdasarkan Tabel 9 Hasil Uji t diketahui nilai Signifikansi (Sig.) variabel Current Ratio (CR) adalah sebesar 0,861, nilai Sig. variabel Debt to Equity Ratio (DER) adalah sebesar 0,534, nilai Sig. variabel Net Profit Margin (NPM) sebesar 0, 946, dan nilai Sig. variabel risiko (Beta) sebesar 0,134. Semua nilai variabel bebas tersebut lebih besar dari 0,05. Maka dapat disimpulkan bahwa hipotesis ditolak. Hal ini berarti Current Ratio (CR), Debt to Equity Ratio (DER), Net Profit Margin (NPM), dan risiko (Beta) secara parsial tidak berpengaruh terhadap return saham di JII pada tahun 2014-2018.

\section{Pembahasan}

Hasil penelitian ini yaitu Current Ratio (CR) secara parsial tidak berpengaruh terhadap return saham di JII tahun 2014-2018. Hasil penelitian ini sejalan dengan hasil penelitian (Haanurat, 2013) dan (Anisa, 2015). Hasil penelitian ini menunjukkan bahwa informasi perubahan CR yang dapat diperoleh dari laporan keuangan tidak berpengaruh pada keputusan atas harga saham di pasar modal syariah. Hal ini mungkin terjadi karena investor dalam melakukan investasi tidak memandang penting rasio aset lancar dengan utang lancar yang dimiliki perusahaan. Rasio likuiditas perusahaan tidak memengaruhi persepsi investor terhadap keuntungan di masa yang akan datang. Namun hasil penelitian ini berbeda dengan hasil penelitian (Prihantini, 2009) yang menyatakan bahwa CR berpengaruh secara signifikan terhadap return saham.

Variabel Debt to Equity Ratio (DER) secara parsial tidak berpengaruh terhadap return saham di JII tahun 2014-2018. Hasil ini sesuai dengan hasil penelitian (Legiman et al., 2015) dan (Haanurat, 2013). Hasil penelitian ini menunjukkan bahwa informasi perubahan DER yang bisa diperoleh dari laporan keuangan tidak berpengaruh pada keputusan atas harga saham di pasar modal Indonesia. Hal ini 
mungkin terjadi karena investor dalam melakukan investasi tidak memandang penting penggunaan utang maupun pengembalian bunga dan pokok utang yang pada akhirnya tidak memengaruhi persepsi investor terhadap keuntungan di masa depan. Selain itu, peningkatan beban terhadap kreditur akan menunjukkan sumber modal perusahaan sangat tergantung pada pihak eksternal, sehingga mengurangi minat investor dalam menanamkan dananya di perusahaan yang bersangkutan. Namun berbeda dengan hasil penelitian (Sudarsono \& Sudiyatno, 2016) dan (Anisa, 2015).

Variabel Net Profit Margin (NPM) secara parsial tidak berpengaruh terhadap return saham di JII tahun 2014-2018. Hasil penelitian ini sesuai dengan hasil penelitian (Ginting, 2013). Secara teori NPM yang tinggi menandakan tingginya kemampuan perusahaan dalam menghasilkan laba, tetapi investor juga memerhatikan faktor lain seperti utang dan beban pajak dari perusahaan tersebut apabila utang dan beban pajak tersebut tinggi maka investor menjadi tidak tertarik terhadap saham perusahaan tersebut. Hasil penelitian ini berbeda dengan hasil penelitian (Martono, 2017) yang menyimpulkan bahwa secara parsial Net Profit Margin berpengaruh positif signifikan terhadap Return saham.

Variabel Beta secara parsial tidak berpengaruh terhadap return saham di JII tahun 2014-2018. Hasil penelitian ini menunjukkan bahwa besar atau kecilnya risiko tidak memengaruhi investor dalam mengambil keputusan investasi dalam saham syariah di JII pada tahun 20142018. Hasil ini berbeda dengan hasil penelitian (Hermuningsih et al., 2018) di perusahaan sektor otomotif di Bursa Efek Indonesia (BEI) dan (Devaki, 2017)) di perusahaan yang termasuk ke dalam LQ 45 di BEI.

\section{SIMPULAN}

\section{Simpulan}

Hasil penelitian ini dapat disimpulkan bahwa hipotesis H1 Current Ratio (CR) secara parsial berpengaruh terhadap return saham di JII pada tahun 2014-2018, ditolak. Hipotesis $\mathrm{H} 2$ bahwa Debt to Equity Ratio (DER) secara parsial berpengaruh terhadap return saham di JII pada tahun 2014-2018, ditolak. Hipotesis H3 bahwa Net Profit Margin (NPM) secara parsial berpengaruh terhadap return saham di JII pada tahun 2014-2018, ditolak. Hipotesis H4 bahwa Beta secara parsial berpengaruh terhadap return saham di JII pada tahun 2014-2018, ditolak. Hipotesis H5 bahwa Current Ratio (CR), Debt to Equity Ratio (DER), Net Profit Margin (NPM), dan risiko (Beta) secara bersama-sama berpengaruh terhadap return saham di JII pada tahun 2014-2018, juga ditolak.

Dengan demikian Current Ratio (CR), Debt to Equity Ratio (DER), Net Profit Margin (NPM), dan risiko (Beta) secara simultan maupun secara parsial tidak berpengaruh terhadap return saham di JII pada tahun 2014-2018. Hal ini mengindikasikan bahwa pasar saham Syariah di JII belum efisien.

\section{Saran}

Hasil penelitian ini masih banyak terdapat kekurangan, oleh karena itu disarankan untuk penelitian yang akan datang agar variabel penelitian ditambah dan periode penelitian diperpanjang jangka waktunya.

\section{REFERENSI}

Anisa, N. (2015). Analisis Faktor-Faktor Yang Mempengaruhi Return Saham (Studi Kasus Pada Perusahaan Sub Sektor Automotive And Components Yang Terdaftar Di Bursa Efek 
Indonesia Periode 2010-2014). Perbanas Review, 1(01).

Antara, S., Sepang, J., \& Saerang, I. S. (2014). Analisis rasio likuiditas, aktivitas, dan profitabilitas terhadap return saham perusahaan wholesale yang terdaftar di Bursa Efek Indonesia. Jurnal EMBA: Jurnal Riset Ekonomi, Manajemen, Bisnis Dan Akuntansi, 2(3).

Arista, D., \& Astohar, A. (2012). Analisis Faktor-Faktor yang Mempengaruhi Return Saham. Jurnal Ilmu Manajemen Dan Akuntansi Terapan (JIMAT), 3(1).

Bursa Efek Indonesia. (2018a). Indeks Saham Syariah. Bursa Efek Indonesia.

https://www.idx.co.id/idxsyariah/indeks-saham-syariah/

Bursa Efek Indonesia. (2018b). Laporan Keuangan dan Tahunan. https://www.idx.co.id/perusahaantercatat/laporan-keuangan-dantahunan/

Bursa Efek Indonesia. (2018c). Ringkasan Indeks. https://www.idx.co.id/datapasar/ringkasanperdagangan/ringkasan-indeks/

Bursa Efek Indonesia. (2018d). Ringkasan Performa Perusahaan Tercatat. https://www.idx.co.id/datapasar/laporan-statistik/ringkasanperforma-perusahaan-tercatat/

Darsono, A. (2005). Pedoman Praktis Memahami Laporan Keuangan. Yogyakarta: Andi.

Devaki, A. (2017). Faktor-faktor yang Mempengaruhi Return Saham pada Perusahaan LQ45 di Bursa Efek Indonesia. Jurnal Benefita: Ekonomi Pembangunan, Manajemen Bisnis \& Akuntansi, 2(2), 157-168.

Dunia Investasi. (2018). Data Harga Saham Bursa Efek Indonesia. https://www.duniainvestasi.com/bei/

Farkhan, F., \& Ika, I. (2012). Pengaruh
Rasio Keuangan terhadap Return Saham Perusahaan Manufaktur di Bursa Efek Indonesia (Studi kasus Pada Perusahaan Manufaktur Sektor Food And Beverage). Value Added: Majalah Ekonomi Dan Bisnis, 9(1), 22860.

Finance.yahoo.com. (2018). Data Historis Harga Saham. Yahoo.Com. https://finance.yahoo.com/

Ghozali, I. (2013). Aplikasi Analisis Multivariate dengan Program IBM SPSS 21 Up Date PLS Regresi. Edisi 7. Semarang: Badan Penerbit Universitas Diponegoro.

Ginting, S. (2013). Analisis Faktor-Faktor yang mempengaruhi return Saham pada perusahaan manufaktur yang terdaftar di Bursa Efek Indonesia. Jurnal Wira Ekonomi Mikroskil: JWEM, 3(1), 31-40.

Gujarati, D. . (2006). Essentials of Econometrics. Mc Graw Hill Companies, Inc. (Terjemahan Julius A. Mulyadi, Dasar-dasar Ekonometrika. Edisi Ketiga, Jilid 1). Jakarta: Penerbit Erlangga.

Haanurat, A. I. (2013). Pengaruh karakteristik perusahaan dan ekonomi makro terhadap return saham syariah yang listing di Jakarta Islamic Index. Jurnal Manajemen Dan Bisnis, 3(2).

Hartono, J. (2016). Teori Portofolio dan Analisis Investasi (Edisi Kese). Yogyakarta: BPFE-Yogyakarta.

Hendriyani, R., Chusna, K., Atmaja, B. T., M, I. I., \& Yanty, R. (2017). Metodologi Penelitian Ekonomi dan Bisnis. Yogyakarta: Fakultas Ekonomi dan Bisnis Islam Universitas Islam Negeri Sunan Kalijaga.

Hermuningsih, S., Rahmawati, A. D., \& Mujino, M. (2018). Faktor-Faktor Yang Mempengaruhi Return Saham. Jurnal Ekonomi Dan Bisnis, 19(3), 
78-89.

Kristiana, V. A. (2013). Analisis FaktorFaktor yang Mempengaruhi Return Saham Investor pada Perusahaan Manufaktur di Bursa Efek Indonesia. Jurnal Ekonomi Dan Kewirausahaan, 12(1).

Kusumo, R. M., \& Siti, M. (2011). Analisis Pengaruh Rasio Keuangan Terhadap Return Saham Pada Perusahaan Non Bank LQ 45. Universitas Diponegoro.

Legiman, F. M., Tommy, P., \& Untu, V. (2015). Faktor-faktor yang mempengaruhi return saham pada perusahaan agroindustry yang terdaftar di Bursa Efek Indonesia periode 2009-2012. Jurnal EMBA: Jurnal Riset Ekonomi, Manajemen, Bisnis Dan Akuntansi, 3(3).

Lingga, M. A. (2019, April 1). KSEI: Potensi Investasi Saham Syariah Sangat Besar. Kompas.Com. https://money.kompas.com/read/201 9/04/01/121227226/ksei-potensiinvestasi-saham-syariah-sangatbesar

Martono \& Harjito, A. (2010). Manajemen Keuangan. Yogyakarta: Penerbit Ekonisia.

Martono, P. A. (2017). Analisis FaktorFaktor Yang Mempengaruhi Return Saham. Media Riset Akuntansi, 6(1).

Murhadi, W. R. (2009). Analisis Saham Pendekatan Fundamental. Jakarta: PT Indeks.

Prihantini, R. (2009). Analisis Pengaruh Inflasi, Nilai Tukar, ROA, DER dan CR Terhadap return Saham (Studi Kasus Saham Industri Real Estate and Property yang Terdaftar di Bursa Efek Indonesia Periode 20032006). Program Pasca Sarjana Universitas Diponegoro.

Raharjo, S. (2014). Uji Multikolonieritas dengan Melihat Nilai Tolerance dan VIF

SPSS. https://www.spssindonesia.com

Raharjo, S. (2017). Cara Mengatasi Masalah Autokorelasi dengan Uji

Run Test dalam SPSS. https://www.spssindonesia.com/201 7/03/autokorelasi-dengan-uji-runtest-spss.html

Sudarsono, B., \& Sudiyatno, B. (2016). Faktor-faktor yang mempengaruhi return saham pada perusahaan property dan real estate yang terdaftar pada bursa efek indonesia tahun 2009 s/d 2014. Jurnal Bisnis Dan Ekonomi, 23(1).

Sugiarto, A. (2011). Analisa Pengaruh Beta, Size Perusahaan, DER dan PBV Ratio Terhadap Return Saham. Jurnal Dinamika Akuntansi, 3(1).

Suhardjono, I. B. (2006). Akuntansi Perbankan. Jakarta: Salemba Empat.

Sumarsan, T. (2010). Sistem Pengendalian Manajemen. Jakarta: PT Indeks.

Thrisye, R. Y., \& Simu, N. (2013). Analisis pengaruh rasio keuangan terhadap return saham BUMN sektor pertambangan periode 2007-2010. Jurnal Ilmiah Akuntansi Dan Bisnis, 8(2), 75-81.

Ulupui, I. G. K. A. (2007). Analisis Pengaruh Rasio Likuiditas, Leverage, Aktivitas, dan Profitabilitas terhadap Return Saham (Studi pada Perusahaan Makanan dan Minuman dengan Kategori Industri Barang Konsumsi di BEJ). Jurnal Ilmiah Akuntansi Dan Bisnis.

Wikipedia. (2019). Jakarta Islamic Index. Wikipedia.

https://id.wikipedia.org/wiki/Jakarta _Islamic_Index

Yuliaratih, K. A. S., \& Artini, L. G. S. (2018). Variabel-Variabel Yang Mempengaruhi Return Saham Pada Perusahaan Property Dan Real Estate Di Bei. E-Jurnal Ekonomi Dan Bisnis Universitas Udayana, 07(05), 
$1495-1528$

https://doi.org/10.24843/eeb.2018.v 07.i05.p10

Yunina, F., \& Shabri, M. (2013). Pengaruh Risiko Sistematik, Leverage, dan Laba terhadap Retrun Saham pada Perusahaan Aneka Industri di Indonesia. Jurnal Akuntansi, 2(12), 56-64.

Zulganef. (2008). Metode Penelitian Sosial dan Bisnis. Yogyakarta: Graha Ilmu. 


\section{Lampiran 1}

\section{Tabel 1 Review Penelitian Terdahulu}

\begin{tabular}{|c|c|c|c|c|c|c|}
\hline No. & Nama Peneliti & Tahun & Judul & $\begin{array}{c}\text { Obyek } \\
\text { penelitian }\end{array}$ & $\begin{array}{c}\text { Variabel } \\
\text { Penelitian }\end{array}$ & Hasil Penelitian \\
\hline 1. & Haanurat, A.I. & 2013 & $\begin{array}{l}\text { Pengaruh Karakteristik Perusahaan dan } \\
\text { Ekonomi Makro Terhadap Return } \\
\text { Saham Syariah yang Listing di Jakarta } \\
\text { Islamic Index. }\end{array}$ & $\begin{array}{l}\text { JII } 2008- \\
2012\end{array}$ & $\begin{array}{l}\text { Return Saham } \\
\text { (Y); EPS, } \\
\text { DER, ROA, } \\
\text { CR, Inflasi, } \\
\text { dan Kurs } \\
\text { Valuta Asing. }\end{array}$ & $\begin{array}{l}\text { ROA dan kurs berpengaruh positif yang } \\
\text { signifikan terhadap return saham syariah, } \\
\text { inflasi berpengaruh signifikan terhadap } \\
\text { return saham, EPS, DER, dan CR tidak } \\
\text { berpengaruh signifikan terhadap return } \\
\text { saham syariah. }\end{array}$ \\
\hline 2. & Anisa, N. & 2015 & $\begin{array}{l}\text { Analisis Faktor-Faktor yang } \\
\text { Mempengaruhi Return Saham (Studi } \\
\text { Kasus Pada Perusahaan Sub Sektor } \\
\text { Automotive and Components yang } \\
\text { Terdaftar di Bursa Efek Indonesia } \\
\text { Periode 2010-2014). }\end{array}$ & $\begin{array}{l}10 \\
\text { perusahaan } \\
\text { sub sektor } \\
\text { otomotif di } \\
\text { BEI 2010- } \\
2014\end{array}$ & $\begin{array}{l}\text { Return Saham } \\
(\mathrm{Y}) ; \mathrm{ROA}, \mathrm{CR}, \\
\text { DER, PER, } \\
\text { dan PBV. }\end{array}$ & $\begin{array}{l}\text { Hanya variabel ROA dan DER } \\
\text { berpengaruh terhadap return saham. CR, } \\
\text { PER dan PBV secara parsial tidak } \\
\text { berpengaruh signifikan terhadap return } \\
\text { saham. }\end{array}$ \\
\hline 3. & $\begin{array}{l}\text { Sudarsono, B., } \\
\text { \& Sudiyatno, B. }\end{array}$ & 2016 & $\begin{array}{l}\text { Faktor-Faktor yang Mempengaruhi } \\
\text { Return Saham Pada Perusahaan } \\
\text { Property dan Real Estate yang } \\
\text { Terdaftar Pada Bursa Efek Indonesia } \\
\text { Tahun } 2009 \text { s/d } 2014 .\end{array}$ & \begin{tabular}{|l}
104 \\
perusahaan \\
property \\
dan real \\
estate di \\
BEI 2009- \\
2014
\end{tabular} & $\begin{array}{l}\text { Return Saham } \\
\text { (Y); Inflasi, } \\
\text { tingkat suku } \\
\text { bunga, nilai } \\
\text { tukar Rupiah } \\
\text { terhadap Dolar } \\
\text { AS, ROA, } \\
\text { DER, dan } \\
\text { Size. }\end{array}$ & $\begin{array}{l}\text { Inflasi berpengaruh negatif signifikan } \\
\text { terhadap return saham, tingkat suku } \\
\text { bunga, nilai tukar dan ukuran (size) } \\
\text { perusahaan berpengaruh positif } \\
\text { signifikan terhadap return saham, ROA } \\
\text { berpengaruh negatif tidak signifikan } \\
\text { terhadap return saham dan DER } \\
\text { berpengaruh positif tidak signifikan } \\
\text { terhadap return saham. }\end{array}$ \\
\hline 4. & $\begin{array}{l}\text { Legiman, F. M., } \\
\text { Tommy, P., \& } \\
\text { Untu, V. }\end{array}$ & 2015 & $\begin{array}{l}\text { Faktor-Faktor yang Mempengaruhi } \\
\text { Return Saham Pada Perusahaan } \\
\text { Agroindustri yang Terdaftar di Bursa } \\
\text { Efek Indonesia Periode 2009-2012. }\end{array}$ & $\begin{array}{l}10 \\
\text { perusahaan } \\
\text { agroindustri } \\
\text { di BEI 2009- } \\
2012\end{array}$ & $\begin{array}{l}\text { Return Saham } \\
\text { (Y); ROA, } \\
\text { ROE, dan DER }\end{array}$ & $\begin{array}{l}\text { ROA berpengaruh signifikan terhadap } \\
\text { return saham. ROE dan DER tidak } \\
\text { berpengaruh signifikan terhadap return } \\
\text { saham. }\end{array}$ \\
\hline 5. & Ginting, S. & 2013 & $\begin{array}{l}\text { Analisis Faktor-Faktor yang } \\
\text { Mempengaruhi Return Saham Pada } \\
\text { Perusahaan Manufaktur yang Terdaftar } \\
\text { di Bursa Efek Indonesia. }\end{array}$ & \begin{tabular}{|l|}
68 \\
perusahaan \\
manufaktur \\
di BEI 2008- \\
2011
\end{tabular} & $\begin{array}{l}\text { Return Saham } \\
\text { (Y); Perubahan } \\
\text { laba usaha, } \\
\text { NPM, PER, } \\
\text { dan PBV. }\end{array}$ & $\begin{array}{l}\text { PBV berpengaruh terhadap Return } \\
\text { saham. Perubahan laba usaha, NPM, dan } \\
\text { PER tidak berpengaruh terhadap Return } \\
\text { saham. }\end{array}$ \\
\hline 6. & Martono, P. A. & 2017 & $\begin{array}{l}\text { Analisis Faktor-Faktor yang } \\
\text { Mempengaruhi Return Saham }\end{array}$ & \begin{tabular}{|l} 
industri \\
barang \\
konsumsi di \\
BEI 2010- \\
2013 \\
\end{tabular} & $\begin{array}{l}\text { Return } \\
\text { Saham(Y); } \\
\text { ROE, NPM, } \\
\text { dan Nilai } \\
\text { Perusahaan. }\end{array}$ & $\begin{array}{l}\text { ROE, NPM, dan Nilai Perusahaan } \\
\text { secara parsial berpengaruh positif dan } \\
\text { signifikan terhadap return saham. }\end{array}$ \\
\hline 7. & $\begin{array}{l}\text { Hermuningsih, } \\
\text { S., Rahmawati, } \\
\text { A. D., \& } \\
\text { Mujino, M. }\end{array}$ & 2018 & $\begin{array}{l}\text { Faktor-Faktor yang Mempengaruhi } \\
\text { Return Saham }\end{array}$ & $\begin{array}{l}\text { perusahaan } \\
\text { sub sektor } \\
\text { otomotif di } \\
\text { BEI 2011- } \\
2015\end{array}$ & $\begin{array}{l}\text { Return Saham } \\
\text { (Y); EVA, } \\
\text { Beta Saham, } \\
\text { Inflasi, Suku } \\
\text { bunga }\end{array}$ & $\begin{array}{l}\text { EVA dan risiko sistematis (beta) } \\
\text { berpengaruh signifikan secara parsial } \\
\text { terhadap return saham. Suku bunga dan } \\
\text { inflasi tidak menunjukkan pengaruh yang } \\
\text { signifikan. }\end{array}$ \\
\hline 8. & Devaki, A. & 2017 & $\begin{array}{l}\text { Faktor-Faktor yang Mempengaruhi } \\
\text { Return Saham Pada Perusahaan LQ } 45 \\
\text { di Bursa Efek Indonesia }\end{array}$ & $\begin{array}{l}21 \\
\text { perusahaan } \\
\text { LQ } 45 \text { di } \\
\text { BEI 2013- } \\
2015 .\end{array}$ & $\begin{array}{l}\text { Return Saham } \\
\text { (Y); DPR, } \\
\text { PER, dan Beta. }\end{array}$ & $\begin{array}{l}\text { DPR tidak berpengaruh terhadap return } \\
\text { saham, sedangkan PER dan beta } \\
\text { berpengaruh terhadap return saham. }\end{array}$ \\
\hline
\end{tabular}

Jurnal Eksos, Juni 2020, Th XVI, No. 1 


\section{Lampiran 2}

\section{Daftar Perusahaan Sampel}

\begin{tabular}{rllrr}
\hline No. & $\begin{array}{l}\text { Kode } \\
\text { Saham }\end{array}$ & \multicolumn{1}{c}{ Emiten } & Tgl Berdiri & \multicolumn{1}{c}{ Tgl Listing } \\
\hline 1 & AKRA & AKR Corporindo Tbk. & 28-Nov-77 & 03-Oct-94 \\
2 & BSDE & Bumi Serpong Damai Tbk. & $16-J a n-84$ & $06-J u n-08$ \\
3 & ICBP & Indofood CBP Sukses Makmur Tbk. & $02-$ Sep-09 & $07-$ Oct-10 \\
4 & INDF & Indofood Sukses Makmur Tbk. & $14-$ Aug-90 & $14-J u l-94$ \\
5 & KLBF & Kalbe Parma Tbk. & $10-$ Sep-66 & $30-J u l-91$ \\
6 & SMRA & Summarecon Agung Tbk. & $26-$ Nov-75 & $07-$ May-90 \\
7 & TLKM & Telekomunikasi Indonesia (Persero) Tbk. & 24-Sep-91 & $14-$ Nov-95 \\
8 & UNTR & United Tractors Tbk. & $19-$ Oct-72 & $19-$ Sep-89 \\
9 & UNVR & Unilever Indonesia Tbk. & $16 / 04 / 1905$ & $11-J a n-82$ \\
10 & WIKA & Wijaya Karya (Persero) Tbk. & $11-$ Mar-60 & 29-Oct-07 \\
\hline
\end{tabular}

